\title{
Comparison of clinicopathologic features of young and older patients with sporadic colorectal adenocarcinoma
}

\author{
Sporadik kolorektal adenokarsinom ile genç ve yaşlı hastaların klinikopatolojik \\ özelliklerinin karşılaştırılması
}

Emre Gönüllü*, Emel Gönüllü, Çağrı Tiryaki, Recai Çapoğlu, Murat Burç
Yazıcloğlu, Mustafa Celalettin Haksal, Ahmet Alponat

Department of General Surgery (E. Gönüllü, MD), Eskisehir State Hospital, TR-26060 Eskişehir, Department of Internal Medicine (E. Gönüllü, MD), Osmangazi University School of Medicine, TR-26000 Eskişehir, Department of General Surgery (Ç. Tiryaki, MD, M. B. Yazıcıoğlu, MD, M. C. Haksal, MD), Kocaeli Derince Training and Research Hospital, TR-41000 Kocaeli, Department of General Surgery (R. Çapoğlu, MD), Erzurum Training and Research Hospital, TR-25240 Erzurum, Department of General Surgery (Prof. A. Alponat, MD), Kocaeli University School of Medicine, TR-41900 Kocaeli

\begin{abstract}
Aim. There is still considerable controversy and debate regarding the features of colorectal cancer in young and older patients. In the present study, the influence of age on clinicopathological characteristics of sporadic colorectal cancer is analyzed retrospectively. Method. A total of 170 cases of colectomy for adenocarcinoma in Kocaeli University Medical School, Turkey, Department of Surgery between January 2001 and September 2005 were studied. Results. Of the 170 patients, $40(23.5 \%)$ were in the $\leq 50$ age group and $130(76.5 \%)$ in the $>50$ age group were included in the study. Statistical tests were applied for the variables. No differences were found between the young and older patients in respect of clinical features, histopathological features, surgical procedures, or post-operative complications. Conclusion. According to this study, there are no differences between young and older patients with sporadic colorectal adenocarcinoma in respect of clinical features, histopathological features, surgical procedures, or post-operative complications. The differences found previously as recorded in the literature may be associated with genetic variations.
\end{abstract}

Keywords: Colorectal, adenocarcinoma, sporadic

\section{Özet}

Amaç. Yaşlı ve genç yaş hastalarda kolorektal kanserlerin özellikleriyle ilgili halen süregelen tartışmalar vardır. $\mathrm{Bu}$ çalışmada yaşın sporadik kolorektal kanserlerin klinikopatolojik karakteristikleri üzerine etkisi retrospektif olarak incelendi. Yöntem. Ocak 2001-Eylül 2005 arasında adenokarsinom nedeniyle Kocaeli Üniversitesi Tıp Fakültesi Genel Cerrahi Kliniği'nde kolektomi yapılan toplam 170 olgu retrospektif olarak incelendi. Bulgular. Yüz yetmiş olgudan 40’1 (\%23,5) elli yaş ve altında, 130’u $(\% 76,5)$ elli yaşın üstünde idi. Elde edilen sonuçlar istatistiksel olarak değerlendirildi. Yaşlı ve genç hasta grupları arasında klinik özellkler, histopatolojik özellikler, uygulanan cerrahi yöntemler veya ameliyat sonrası komplikasyonlar açısından fark bulunmadı. Sonuç. Bu çalışmaya gore sporadik kolerektal adenokarsinomlu genç ve yaşlı hastalar arasında kilnik özellikler, histopatolojik özellikler, uygulanan cerrahi yöntemler veya ameliyat sonrası komplikasyonlar açısından fark yoktur. Literatürlerde belirtilen daha once saptanmış olan farklar gentetik varyasyonlarla ilişkili olabilir.

Anahtar sözcükler: Kolorektal, adenokarsinom, sporadik

Geliş tarihi/Received: August 16, 2013; Kabul tarihi/Accepted: March 05, 2014

*Corresponding author:

Dr. Emre Gönüllü, Genel Cerrahi Servisi, Eshişehir Devlet Hastanesi, TR-26060 Eskişehir. E-mail: emregonullu@yahoo.com 


\section{Introduction}

There is still considerable debate regarding the features of colorectal cancer in young and older patients. Age is reported as a risk factor for carcinogenesis that may affect cancer behavior both positively and negatively. In the present study, the influence of age on the clinicopathological characteristics of sporadic colorectal cancer is analyzed retrospectively, covering patients from presentation through the perioperative process.

\section{Material and methods}

Data on the clinical and histopathological features of colorectal cancer were collected from specially designed cancer registry and medical records. A total of 327 cases of people who had undergone colectomy for adenocarcinoma in the Department of Surgery at Kocaeli University Medical School, Turkey, between January 2001 and September 2005 were studied. Since only distinct cases were to be considered, three cases with familial adenomatous polyposis and two with hereditary non-polyposis colorectal cancer were excluded from the study. Another 152 patients for whom all the data could not be accessed or which was lost to follow-up were also excluded from the study. The study was thus concluded with the remaining 170 patients.

\section{Statistical analysis}

Statistical analysis was performed with the packed program SPSS for Windows, version 10.1. Chi-square, Student F, and Mann-Whitney U tests were applied to the variables.

\section{Results}

The patients were divided into two groups according to age defined as 50 and under and over 50 years (yrs) of age. The mean age of the younger group was 42.5 (21-50) and the older 64.8 (51-83). A total of 170 patients, 40 in the $\leq 50$ age group (23.5\%) and 130 in $>50$ years of age group $(76.5 \%)$ were included in the study. There were no statistically significant differences between the two groups for gender, presenting symptoms of rectal bleeding, changes of defecation habits, abdominal pain, signs of bowel obstruction, weight loss, duration of symptoms, localization of tumor, tumor stage as reflected by the American Joint Committee on Cancer (AJCC)/International Union Against Cancer (UICC) tumor-node-metastasis (TNM) system [1], or level of carcinoembryonic antigen (CEA) levels (Table 1).

The macroscopic features of 35 patients $(87.5 \%)$ in the younger group were ulcerative, four patients $(10 \%)$ were polypoid, and one $(2.5 \%)$ patient was scirrous. Among the older group, 118 patients $(91 \%)$ were ulcerative, eight $(6 \%)$ were polypoid, and one (3\%) patient was scirrous. These differences between the two groups were not significant. The other histopathological findings-mean diameter of tumor size, depth of tumor invasion, differentiation, vascular/lymphatic/perineural invasion, synchronous or metachronous tumor with colorectal or extracolonic cancer, and TNM stage-also showed no statistical difference (Table 2).

All the patients were given a laparatomy. Thirty six $(90 \%)$ patients from the younger group and $110(85 \%)$ from the over 50 years group had radical surgery. Again, there were no statistical differences between the two groups in respect of radical and palliative surgery procedures and post operative complications (Table 3 , Table 4). 
Table 1. Clinical features and CEA levels of patients with colorectal carcinoma.

\begin{tabular}{llll}
\hline Gender & $\mathbf{5 0}$ yrs (\%) & $\mathbf{> 5 0}$ yrs (\%) & Significance (p) \\
\hline Male & $23(57.5 \%)$ & $77(59.2 \%)$ & 0.846 \\
Female & $17(42.5 \%)$ & $53(40.8 \%)$ & \\
Total & 40 & 130 & \\
\hline Symptoms & & \\
\hline Rectal bleeding & $29(72.5 \%)$ & $84(64.6 \%)$ & 0.40 \\
Change of defecation habits & $19(47.5 \%)$ & $57(43.8 \%)$ & 0.74 \\
Abdominal pain & $13(32.5 \%)$ & $53(40.7 \%)$ & 0.35 \\
Signs of bowel obstruction & $7(17.5 \%)$ & $28(21.5 \%)$ & 0.58 \\
Weight loss & $12(30 \%)$ & $22(16.9 \%)$ & 0.5 \\
Duration of symptoms (months) & $9.8 \pm 13.39$ & $12.63 \pm 24.49$ & 0.49 \\
Syncron with polip & 9 & 31 & 0.86 \\
\hline Tumor localization & & & \\
\hline Right colon & $6(15 \%)$ & $27(20.7 \%)$ & 0.24 \\
Left colon & $11(27.5 \%)$ & $48(36.9 \%)$ & \\
Rectum & $23(57.5 \%)$ & $55(42.3 \%)$ & \\
\hline Clinical Stage & & \\
\hline I & $5(12.5 \%)$ & $12(9.2 \%)$ & 0.72 \\
II & $23(57.5 \%)$ & $71(54.6 \%)$ & \\
III & $8(20 \%)$ & $25(19.2 \%)$ & \\
IV & $4(10 \%)$ & $22(16.9 \%)$ & \\
\hline CEA level (ng/dL) & & \\
\hline$<3.5$ & $19(47.5 \%)$ & $52(40 \%)$ & 0.53 \\
$3.5-10$ & $9(22.5 \%)$ & $41(31.5 \%)$ & \\
$>10$ & $12(30 \%)$ & $37(28.4 \%)$ & \\
\hline
\end{tabular}

Table 2. Histopathological features of tumors.

\begin{tabular}{|c|c|c|c|}
\hline & $\leq 50$ yrs & $>50$ yrs & Significance (p) \\
\hline \multicolumn{4}{|l|}{ Macroscopic type } \\
\hline Ulcerative & $35(87.5 \%)$ & $118(90.7 \%)$ & 0.80 \\
\hline Polypoid & $4(10 \%)$ & $8(6.1 \%)$ & \\
\hline Scirrous & $1(2.5 \%)$ & $4(3.0 \%)$ & \\
\hline Mean diameter of tumor size & $4.86 \pm 2.23$ & $5.16 \pm 2.27$ & 0.46 \\
\hline \multicolumn{4}{|l|}{ Depth of tumor invasion } \\
\hline T 1 & $2(5 \%)$ & $4(3.07 \%)$ & 0.72 \\
\hline T 2 & $8(20 \%)$ & $18(13.8 \%)$ & \\
\hline T 3 & $25(62.5 \%)$ & $89(68.5 \%)$ & \\
\hline $\mathrm{T} 4$ & $5(12.5 \%)$ & $19(14.6 \%)$ & \\
\hline \multicolumn{4}{|l|}{ Differentiation } \\
\hline Well & $14(35 \%)$ & $38(29.2 \%)$ & 0.63 \\
\hline Moderate & $24(60 \%)$ & $88(67.7 \%)$ & \\
\hline Poor & $2(5 \%)$ & $4(3.07 \%)$ & \\
\hline Mucin production & $9(22.5 \%)$ & $14(10.8 \%)$ & 0.058 \\
\hline Vascular/lymphatic invasion & $5(12.5 \%)$ & $10(7.7 \%)$ & 0.35 \\
\hline Perineural invasion & $1(2.5 \%)$ & $5(3.8 \%)$ & 1.0 \\
\hline Lymphocyte infiltration & $1(2.5 \%)$ & $3(2.3 \%)$ & 1.0 \\
\hline \multicolumn{4}{|l|}{ Synchronous tumor } \\
\hline Colorectal cancer & $0(0 \%)$ & $3(2.3 \%)$ & 0.62 \\
\hline Extracolonic cancer & $1(2.5 \%)$ & $3(2.3 \%)$ & \\
\hline \multicolumn{4}{|l|}{ Metachronous tumor } \\
\hline Colorectal cancer & $0(0 \%)$ & $3(2.3 \%)$ & 0.38 \\
\hline Extracolonic cancer & $0(0 \%)$ & $3(2.3 \%)$ & \\
\hline \multicolumn{4}{|l|}{ TNM stage } \\
\hline I & $7(17.5 \%)$ & $18(13.8 \%)$ & 0.14 \\
\hline II & $14(35 \%)$ & $59(45.4 \%)$ & \\
\hline III & $17(42.5 \%)$ & $35(26.9 \%)$ & \\
\hline IV & $2(5 \%)$ & $18(13.8 \%)$ & \\
\hline
\end{tabular}


Table 3. Surgical procedures performed.

\begin{tabular}{|c|c|c|c|c|c|c|c|}
\hline \multirow[b]{2}{*}{ Type of surgery } & \multicolumn{2}{|c|}{$\begin{array}{c}\text { Radical } \\
\text { procedure }\end{array}$} & \multicolumn{2}{|c|}{$\begin{array}{l}\text { Palliative } \\
\text { procedure }\end{array}$} & \multicolumn{2}{|c|}{$\begin{array}{c}\text { Total } \\
\text { (groups) }\end{array}$} & \multirow[t]{2}{*}{$\begin{array}{l}\text { Total } \\
\text { (combined) }\end{array}$} \\
\hline & $\leq 50$ yrs & $>50$ yrs & $\leq 50$ yrs & $>50$ yrs & $\leq 50$ yrs & $>50$ yrs & \\
\hline Right hemicolectomy & 4 & 19 & 1 & 6 & 5 & 25 & $30(17.6 \%)$ \\
\hline Transverse colectomy & 1 & 0 & 0 & 0 & 1 & 0 & $1(0.5 \%)$ \\
\hline Left hemicolectomy & 0 & 9 & 0 & 1 & 0 & 10 & $10(5.8 \%)$ \\
\hline Sigmoidectomy & 2 & 9 & 0 & 2 & 2 & 11 & $13(7.6 \%)$ \\
\hline Anterior resection & 5 & 8 & 0 & 2 & 5 & 10 & $15(8.8 \%)$ \\
\hline Low ant. resection & 12 & 31 & 0 & 1 & 12 & 32 & $44(25.8 \%)$ \\
\hline Abdominoperineal resection & 8 & 20 & 2 & 3 & 10 & 23 & $33(19.4 \%)$ \\
\hline Total colectomy & 1 & 3 & 0 & 0 & 1 & 3 & $4(2.3 \%)$ \\
\hline Colostomy & 0 & 0 & 1 & 2 & 1 & 2 & $3(1.7 \%)$ \\
\hline Hartmann procedure & 2 & 11 & 0 & 3 & 2 & 14 & $16(9.4 \%)$ \\
\hline Local excision & 1 & 0 & 0 & 0 & 1 & 0 & $1(0.5 \%)$ \\
\hline Total & $\begin{array}{l}36 \\
(90 \%)\end{array}$ & $\begin{array}{l}110 \\
(84.6 \%)\end{array}$ & $\begin{array}{l}4 \\
(10 \%)\end{array}$ & $\begin{array}{l}20 \\
(15.4 \%)\end{array}$ & $\begin{array}{l}40 \\
(23.5 \%)\end{array}$ & $\begin{array}{l}130 \\
(76.5 \%)\end{array}$ & 170 \\
\hline
\end{tabular}

Table 4. Post-operative complications.

\begin{tabular}{llll}
\hline Complications & $\mathbf{5 0 0}$ yrs $\mathbf{( \% )}$ & $\mathbf{> 5 0}$ yrs $\mathbf{( \% )}$ & Significance $(\mathbf{p})$ \\
\hline Pulmonary infection & $0(0 \%)$ & $2(1.5 \%)$ & 0.58 \\
Wound infection & $1(2.5 \%)$ & $5(3.8 \%)$ & 0.57 \\
Evisceration & $1(2.5 \%)$ & $10(7.6 \%)$ & 0.46 \\
Ileus & $2(5 \%)$ & $9(6.9 \%)$ & 0.50 \\
Anastomotic leakage & $0(0 \%)$ & $2(1.5 \%)$ & 0.58 \\
\hline
\end{tabular}

\section{Discussion}

Colorectal cancer (CRC) is one of the most common cancers that localizes to the large intestine and rectum. It is the most frequent cancer after lung, breast, and ovarian cancer $[2,3]$. The disease occurs more commonly in the elderly population $[4,5]$. It is not clear whether age influences the features of colorectal carcinoma, with different studies showing conflicting results. Some studies have showed younger patients as tending to be at a more advanced stage at the time of diagnosis, while others have found that as age increases so is the tumor stage at diagnosis more advanced and tumor differentiation increased [6-10]. There is thus considerable debate regarding the features of colorectal cancer in younger and older patients. Advanced stage or poorly differentiated tumor at presentation, along with delay in diagnosis are considered as poor prognostic factors, but controversies exist regarding this issue, too [6-10].

Some studies have suggested that most young patients with colorectal tumors presented with an advanced stage tumor [5]. In our study, both the younger and older patients presented mostly at stage II, without any significant difference. Additionally, the symptoms of rectal bleeding, change of defecation habits, abdominal pain, signs of bowel obstruction, weight loss, and duration of symptoms did not predict any difference between the two groups.

Carcinoembryogenic antigen (CEA) is the most investigated, most widely used and available tumor marker for colorectal carcinoma. High preoperative serum levels have been shown to be associated with recurrence and poor prognosis [11, 12]. Most of the patients here had a CEA level of $<3.5 \mathrm{ng} / \mathrm{dL}$, with $30 \%$ of younger and $28.4 \%$ of older patients having a CEA level of $>10 \mathrm{ng} / \mathrm{dL}$. The findings were similar for the two groups. These findings indicated that in spite of the lack of differences between the groups, CEA can be low and less than one in three patients may have higher levels at presentation. 
Tumors in younger patients with colorectal cancer have been demonstrated to be associated with more aggressive histopathological findings [13]. Our histopathological findings conflict with this study and lead us to wonder whether ethnic groups and genetic variations may play a causal role in several differences related to the presenting features. A radical approach had been chosen here for most of the patients with colorectal carcinoma, and only a small group of patients had undergone a palliative procedure. The choice of procedure did not make a difference, and these radical or palliative procedures caused similar types and levels of complications between the two groups.

Concluding, there is still considerable debate regarding the features of colorectal cancer in younger and older patients. According to our study, there are no major differences between the young and old with respect to sporadic colorectal adenocarcinoma in terms of clinical features, histopathological features, surgical procedures, or post-operative complications. The contradictory differences found in previous the studies in the literature may be associated with genetic variations.

\section{References}

1. Fleming ID, Cooper JS, Henson DE, Hutter RVP, Kennedy BJ, Murphy GP. American Joint Committee on Cancer (AJCC). AJCC cancer staging manual. 5th ed. Philadelphia, PA, USA: Lippincott-Raven, 1997.

2. Puppa G, Sonzogni A, Colombari R, Pelosi G. TNM staging system of colorectal carcinoma: A critical appraisal of challenging issues. Arch Pathol Lab Med. 2010; 134: 837-52.

3. Belov L, Zhou J, Christopherson RI. Cell surface markers in colorectal cancer prognosis. Int J Mol Sci. 2010; 12: 78-113.

4. Alici S, Aykan NF, Sakar B, Bulutlar G. Colorectal cancer in young patients: Characteristics and outcome. Tohoku J Exp Med. 2003; 199: 85-93.

5. Lin JT, Wang WS, Yen CC, Liu JH. Outcome of colorectal carcinoma in patients under 40 years of age. Gastroenterol Hepatol. 2005, 20: 900-5.

6. Endreseth BH, Romundstad P, Myrvold HE, Hestvik UE. Rectal cancer in the young patient. Dis Colon Rectum. 2006; 49: 993-1001.

7. Chiang JM, Chen MC, Changchien CR, Chen JS. Favorable influence of age on tumor characteristics of sporadic colorectal adenocarcinoma: patients 30 years of age or younger may be a distinct patient group. Dis Colon Rectum. 2003; 46: 904-10.

8. Fazeli MS, Adel MG, Lebaschi AH. Colorectal carcinoma: A retrospective, descriptive study of age, gender, subsite, stage, and differentiation in Iran from 1995 to 2001 as observed in Tehran University. Dis Colon Rectum. 2007; 50: 990-5.

9. Mostafa G, Matthews BD, Norton HJ, Kercher KW, Sing RF, Heniford BT. Influence of demographics on colorectal cancer. Am Surg. 2004; 70: 259-64.

10. Li M, Li JY, Zhao AL, Gu J. Do young patients with colorectal cancer have a poorer prognosis than old patients? J Surg Res. 2011; 167: 231-6.

11. Huh JW, Oh BR, Kim HR, Kim YJ. Preoperative carcinoembryonic antigen level as an independent prognostic factor in potentially curative colon cancer. J Surg Oncol. 2010; 101: 396-400.

12. Wang WS, Lin JK, Lin TC, Chiou TJ. Tumor marker CEA in monitoring of response to tegafur-uracil and folinic acid in patients with metastatic colorectal cancer. Hepatogastroenterology. 2002; 49: 388-92.

13. Liang JT, Huang KC, Cheng AL, Jeng YM. Clinicopathological and molecular biological features of colorectal cancer in patients less than 40 years of age. Br J Surg. 2003; 90: 205-14. 